\title{
Students' Responses towards D-PBL Learning Model in the Material of Payment System and Means of Economic Exchange
}

\author{
Noviyana SARI ${ }^{1}$,Sigit SANTOSO ${ }^{2}$, Wiedy MURTINI ${ }^{3}$
}

\begin{tabular}{l} 
ARTICLE INFO \\
\hline Article History: \\
Received 27.02.2018 \\
Received in revised form \\
14.04 .2018 \\
Accepted \\
Available online 01.07 .2018
\end{tabular}

\begin{abstract}
This study aims to determine the student's response to the D-PBL learning model on the material of payment system and the means of economic exchange. The research method used was preexperimental design using one-shot case study design. The sample of this research were 21 tenth grade students of high schools in Indonesia. The data collection methods used in this study were interviews, observations and questionnaires. Observations were used to assess the syntax implementation of the D-PBL learning model in the classroom learning process, and the questionnaire was used to find out the students' responses to the D-PBL model covering the display aspect, material relevance aspects, contextual learning aspects, and advantage aspects. The observation data were analysed using Guttman scale while the students' responses were analysed using five-point Likert scale. The results showed that the syntaxes implementation of the D-PBL model in the classroom learning process was $100 \%$, and the average score of the students' re sponses to the D-PBL model was categorized as very good with a score of $91.9 \%$. This study also showed that the students responded very positively to the D-PBL learning model. This indicates that the DPBL learning model aims to construct the knowledge of the students through meaning ful problem solving as well as to assist them in understanding the material of the payment system and the means of economic exchange.
\end{abstract}

Keywords:

(C) 2018IJERE. All rights reserved

D-PBL model, Response, Payment System and Means of Economic Exchange.

INTRODUCTION

Learning is a system, consisting of various components that are interconnected with one another that includes objectives, materials, methods and evaluation (Rusman, 2012). Learning is a process to help students to learn according to their needs and interests (Cahyo, 2013). Baharudin (2010) stated that learning process is the process of interaction between teachers and students, related to learning materials that are complex and full of uncertainty. Learning is said to be complex because the interaction between teachers and students is complex since it involves thoughts, emotions, imaginations and attitudes that interact simultaneously. Learning is also said to be full of uncertainty because the students' thoughts, emotions and imagination are unstable and unpredictable. Thus, the result of learning becomes subjective.

Interesting learning makes students more motivated in learning activities. Bakar (2014) said that motivation is an internal and external impulse that causes a person to act tow ard the goal, so it is expected that there will be a change. The planning of Interesting learning needs to be supported by well-structured learning tools (Chinnapan and Tajudin, 2016). In carrying out the learning process, teachers need lesson planning, both in the aspects of cognitive, affective, and psychomotor. The quality of teachers becomes a benchmark of educational quality. Ninlaw an (2015) pointed out that teachers play an important $r$ ole in educating, motivating and making effective classroom management with the following 5 characteristics: (1) Professionalism in performing their duties, (2) Continuous development of competence, (3) Being able to produce innovation and teaching technique, (4) Ability in understanding the characteristics of students, (5) Ability to use foreign language.

NCSS (2000) stated that Economics, as a branch of science, is classified as social science. Economics in learning is a study of people's and societal behavior in choosing how to use scarce resources that have several alternative uses, in order to produce various commodities and distribution, both at present and in the future to various individuals and groups within a society (Sukwiaty, 2009). In the national education

1 noviyana.arifin@student.uns.ac.id, orcid.org/0000-0003-0396-8773 
Sari,N., Santoso,S. \& Murtini,W.(2018) .Students' responses tow ards D-Pbl learning model in the material of payment system and means of economic exchange. International Journal of Educational Research

Review,3(3),17-22.

curriculum, Economics aims to equip students to think logically, analytically, systematically, critically and creatively so that they have high-level thinking skills through the given learning instruments.

Based on the observation in one school, Economics learning implemented in that school only emphasized on the product aspect regardless of the process aspect. Learning w as still teacher-centered. The teacher just gave theory, and the students tended to memorize. The students' responses tow ards the innovations in learning were never seen. The presentation of Economics subject should be carried out in a balanced way. The students not only get know ledge products from teachers but also have to experience the process of acquiring that knowledge. Moreover, based on a social constructivist perspective on learning, the student's psychological status should not be ignored in the learning process (Liu, et al, 2014). Therefore, the identification of the mental state of the students is an essential step to increase teachers 'awareness of the students' early conceptions which can be said to be internal students (McNeil, 2015). This is considered very important before and after learning process.

The results of interviews with tenth grade students of one high school showed that in the Economics learning activities, the teachers only explain the material with lecturing method and provide exercises. This makes the students less active because the teacher-provided lessons are only one-way, in which the students only listen and record teacher explanations. The needs analysis obtained from the student interviews showed that the desired learning is learning that encourages students to play an active role in developing thinking skills and enhancing cooperation to solve a problem. Based on this, there are innovative efforts in improving the quality of learning by using student-centered learning model (student oriented), so that students are able to construct knowledge, and able to empower their ability through one of D-PBL learning model. Arends (2001) stated that teachers need to differentiate instruction in the form of customizing the learning model to meet student needs. Bhattacharjee, et al. (2018) came up with their idea that conventional learning model will make students feel bored, so teachers need innovative efforts to create a fun learning. DPBL learning model aims to construct students' knowledge through meaningful problem solving so as to create learning that gives rise to cognitive conflict. Students not only work in low-thinking areas but also refer to Higher Order Thinking Skill (HOTS). Brookhart (2010) said that HOTS is the highest level of the hierarchical Bloom's cognitive taxonomy. HOTS is a high-level thinking skill involving cognitive and affective domains in obtaining information or solving problems and taking a decision (Yee, at al, 2015). According to Khan and Masood (2015) HOTS, in learning is the cognitive domain of C4-C6 which includes the ability to analyse, evaluate, and create. D-PBL learning model is a combination of pre-existing models; they are Discovery Learning model and Problem Based Learning (PBL) model. D-PBL model uses a constructivism approach through group collaboration to solve a problem through observation and conclusion drawing in achieving the learning objectives so that students gain experience from the learning process they find themselves.

In the national education curriculum, payment system and means of economic exchange become a teaching material in high school that discusses the agreed way to transfer a value in the exchange of goods and services in an economy.

This study aims to determine the students' responses to D-PBL model on the material of payment system and means of economic exchange in the tenth grade of senior high schools in Indonesia. In the national education curriculum, payment system and means of economic exchange become a teaching material in high school that discusses the agreed way to transfer a value in the exchange of goods and services in an economy.

\section{METHOD}

The research method used was pre-experimental using a one-shot case study design implemented to determine the impact of a treatment imposed on a study without any comparison class. Sugiyono (2015), the population in research was the tenth grade students of one senior high school in Indonesia who had not received the material of payment system and means of economic exchange. The sample in the study was 21 tenth grade students of one senior high school students in Indonesia.

\section{Material}


Sari,N., Santoso,S. \& Murtini,W. (2018) .Students' responses tow ards D-Pbl learning model in the material of payment system and means of economic exchange. International Journal of Educational Research Review,3(3),17-22.

The data collection techniques were an observation sheet to assess the implementation of D-PBL model learning syntaxes and the questionnaire of the students' responses which comprises of 22 statements. The results of the observation sheet were analysed using Guttman scale, while the student's questionnaire was assessed usingfive-point Likert scale. The data of students' responses to the application of D-PBL learning model were analysed by calculating the percentage of statement items through the score of responses given by the students.

\section{Data Analyses}

For data analyses, the students' questionnaire were assessed using five-point Likertscale.Then, the scores were interpreted to reveal the descriptive information. The analyses revealed the following descriptive information; $0 \%-20 \%$ : Very Poor, $21 \%-40 \%$ : Poor, $41 \%-60 \%$ : Moderate, $61 \%-80 \%$ : Good, $81 \%$ 100\%: Very Good.

\section{FINDINGS}

The sample in the study was 21 tenth grade students of one high school in Indonesia. In the learning process, the students were taught by using D-PBL learning model. The data collection techniques of this research were observation sheet to assess the ithe stages of the implementation of learning design using DPBL learning model and the questionnaire of the students' responses comprising of 22 statements. The instruments in this study were lesson plan, student worksheets, and the questionnaires of the students' responses that had been validated by the expert of teaching instruments and learning models. The learning process of D-PBL model was analysed using 8 syntaxes of D-PBL learning model; they are: (orient student to the problem, organize students for study, teams, problem statement with team study, data collecting with teaching group, data processing, verification with whole class units, generalization). The results of the observation sheet analysis are presented in Table 1 and the students' responses' recapitulation is presented in Table 2 as follows.

Table 1.The Analysis Resultof theObservationSheet of SyntaxImplementation of D-PBL Model

\begin{tabular}{lcc}
\hline \multicolumn{1}{c}{ Learning Steps } & Respondents' Responses \\
\cline { 2 - 3 } & Meeting 1 & Meeting 2 \\
\hline Stage 1. Orient student to the problem & 100 & 100 \\
Stage 2. Organize students for study & 100 & 100 \\
Stage 3. Teams & 100 & 100 \\
Stage 4. Problem statement with team study & 100 & 100 \\
Stage 5. Data collecting with teaching group & 100 & 100 \\
Stage 6. Data processing & 100 & 100 \\
Stage 7. Verification with whole class units & 100 & 100 \\
Stage 8. Generalization & 100 & 100 \\
\hline Average & 100 & 100 \\
\hline
\end{tabular}

Table 1 shows that the use of D-PBL model at the first or second meeting has been in accordance with the stages of the implementation of learning design with 100\% percentage or good categorization.

Table 2 The results of Questionnaire Analysis of the Students' Responses tow ards D-PBL Model

\begin{tabular}{lcl}
\multicolumn{1}{c}{ Indicators } & $\Sigma$ & Responses \\
\hline Display Aspect & 92.1 & Very Good \\
Material Relevance Aspect & 91.2 & Very Good \\
Contextual Learning Aspect & 91 & Very Good \\
Advantage Aspect & 93.1 & Very Good \\
\hline Average & 91.9 & Very Good \\
\hline
\end{tabular}

Table 2 shows that the percentage of students' responses to D-PBL model on the material of payment system and means of economic exchange of the tenth grade of senior high school on display aspect indicator 
Sari,N., Santoso,S. \& Murtini,W.(2018) .Students' responses tow ards D-Pbl learning model in the material of payment system and means of economic exchange. International Journal of Educational Research

Review,3(3),17-22.

$92,1 \%$ for material relevance aspect $91,2 \%$ aspect of contextual learning $91 \%$, and advantage aspect of $93,1 \%$. Overall, the average students' responses obtained in this study were $91.9 \%$ with very good category.

\section{RESULT, DISCUSSION, AND SUGGESTIONS}

The present studyis to determine the students' responses to the D-PBL learning model on the material of payment system and the means of economic exchange. This study was conducted twice, where each meeting lasted for $3 \times 45$ minutes. In the first meeting, the teacher taught the economic payment system. The second meeting material $w$ as the means of economic exchange.

In this research, the application of D-PBL model in learning process consists of 8 stages:

1. Orient Student To the Problem, at this stage the teacher explains the learning objectives, directs the student into the model that will be developed and motivate them to engage in problem-solving activities.

2. Organize Student for Study, at this stage the teacher generates the students interest in learning materials by helping students define and organize as many relevant issues as possible.

3. Teams, at this stage the teacher directs the students to form groups of 4-5 members.

4. Problem Statement with Team Study, at this stage the teacher provides an opportunity for the students to identify as many problems as relevant to the teaching materials, then select it and submit a temporary answer in the form of hypothesis related to the learning material.

5. Data Collecting with Teaching Group, at this stage the teacher facilitates the student s in collecting relevant information, reading the literature, observing objects, interviewing with resource persons, conducting a test to prove whether or not the hypothesis is true.

6. Data Processing, in this stage the teacher facilitates the students to process data and information obtained in groups to solve the problem.

7. Verification with Whole-Class Unit, at this stage the teacher helps the students to reflect on his investigation to prove the hypothesis and the processes that have been applied through the presentation activity in front of the class. Then they justify through the classical teaching of the wrong concepts.

8. Generaliztion, at this stage the teacher with the students concludes the learning process, gives reinforcement and recommends the values that should be implemented in life.

Poerwadarminta (2003) stated that a response means the reaction or the response of acceptance or rejection, as well as indifference to what is communicated by the communicator in the message. The students' responses related to D-PBL model display aspects clearly indicate the role of students both individually and in groups. The phases in the D-PBL syntaxes encourage students to construct and find concepts in the learning activities, so that the teacher-student relationship pattern in the D-PBL model shows the teacher's role as a facilitator, and the learning is student-oriented. The results show ed that the average of the students' responses for the display of D-PBL learning model was $92.1 \%$ with very good category. This indicates that the learning was in accordance with D-PBL model syntaxes, learning objectives, and learning styles expected by the students.

The material relevance aspect in D-PBL model is the consistency of learning materials with the objectives of student learning, conformity with the way of learning and the stage of student development. The results showed that the average of students' responses to the relevance of the material in following the learning process using D-PBL model were $91.2 \%$ with very good category. This indicates that learning using the D-PBL model helps students to understand the learning material easily, so that the material provides usefulness in student life. Abidin (2006) explained that when teachers explain the knowledge to be learned and can be applied in everyday life, it will help students in the learning process.

The students' responses to the contextual learning aspect using D-PBL model clearly explained the role of students in working together in teams to solve problems. The results showed that the average of students' responses related to contextual learning aspect in D-PBL model was 91\% with very good category. This 
Sari,N., Santoso,S. ,\& Murtini,W.(2018) .Students' responses tow ards D-Pbl learning model in the material of payment system and means of economic exchange. International Journal of Educational Research Review,3(3),17-22.

suggests that learning process using the D-PBL model helps students to broaden their knowledge of the material learned through the social context presented.

The students' responses related to the advantage aspects of learning through the D-PBL model clearly showed how D-PBL model can help the students more easily in understanding the materials, improving thinking skills and making learning more active. The results showed that the average of student responses related to the aspects of benefit in the D-PBL model was $93.1 \%$ with very good category. This suggests that the learning process using the D-PBL model helps students construct and explore capabilities. The students enjoyed and were interested in learning because they invited the students to observe so that students saw directly and felt the learning process, explored the curiosity because learning had a problem to solve and made the students more active in learning because they can discuss with the group, so as to increase the attention of students to be able interpret the learning process.

Based on the results of this study, the implementation of learning process using D-PBL model in the tenth grade of senior high school on the material of payment system and the means of economic exchange showed that the students' responses were $91.9 \%$ with very good category. This suggests that learning using D-PBL model fits well with the needs and learning styles of the students, and phases in D-PBL syntaxes encourage the students to construct and discover concepts in learning activities, thereby increasing the students' attention to be able to interpret the learning process.

Based on the results of this study, the implementation of learning process using D-PBL model in the tenth grade of senior high school on the material of payment system and the means of economic exchange showed that the implementation of D-PBL learning model on the material of payment system and the means of economic exchange was done with good category (100\%) and the students' responses were $91.9 \%$ with very good category. This suggests that learning using D-PBL model fits well with the needs and learning styles of the students, and phases in D-PBL syntaxes encourage the students to construct and discover concepts in learning activities, thereby increasing the students' attention to be able to interpret the learning process. Based on the results of the research and the conclusion above, it is suggested that other researchers can conduct further researches by measuring the activity and learning outcomes of the students and examine the use of D-PBL learning model on different materials.

\section{REFERENCES}

Arends, R.I. (2001). Learning to teach (Fifth edition).Singapore: McGraw-Hill.

Baharudin.(2010). Teori belajardanpembelajaran.Yogjakarta: Ar-Ruz Media.

Bakar, R. (2014). The effect of learning motivation on student's productive competencies in vocational high school, west sumatera. International Journal of Asian Social Science, 4(6), 722-732.

Bhattacharjee, D., Paul, A., Kim, J.H., \&Karthigaikumar, P. (2018). An immersive learning model using evolutionary learning.Computers and Electrical Engineering, 65, 236-249.

Brookhart, S.M. (2010). How to asses higher order thinking skills in your classroom. Virginia: ASCD.

Cahyo, A.N. (2013). Panduan aplikasi teori-teori belajar mengajar. Jogjakarta: DIV A Press .

Chinnapan, M., \&Tajudin, N.M. (2016). The link between higher order thingking skills, representation and concepts in enhancing timss tasks. International Journal of Instruction, 9(2), 199-214.

Khana, F.M.A., \&Masood, M. (2015).The effectiveness of an interactive multimedia courseware with cooperative mastery approach in enhancing higher order thinking skills in learning cellular respiration.Social and Behavioral Sciences, 176, 977-984.

Liu, C, et al. (2014). An exploration of secondary students' mental states when learning about acid and bases.Research in Science Education, 44, 133-154. 
Sari,N., Santoso,S. ,\& Murtini,W. (2018) .Students' responses tow ards D-Pbl learning model in the material of payment system and means of economic exchange. International Journal of Educational Research Review,3(3),17-22.

McNeil, S. (2015). Visualizing mental models: Understanding cognitive change to support teaching and learning of multimedia design and development. Education Tech Research Dev, 63, 73-96.

National council for the social studies. (2000). Science-Technology-Society (STS) in social studies. Washington DC: NCSS.

Ninlawan, G. (2015). Factors which affect teachers' professional development in teaching innovation and educational technology in the 21st century under the bureau of special education, office of the basic education commission.Social and Behavioral Sciences, 197, 1732-1735.

Poerwadarminta, W.J.S. (2003). Kamus umum bahasa indonesia. Jakarta: Balai Pustaka.

Sugiyono.(2015). Metode penelitian pendidikan (Pendekatan Kuantitatif, Kualitatif, dan RED). Bandung: Alfabeta.

Sukwiaty. (2009). Ekonomi sma kelas X. Jakarta: Yudistira.

Yee, M.H., Yunos, J.Md.,Othman,W., Hassan,R., Tee,T.K., \& Mohamad, M.M. (2015).Disparity of learning styles and higher order thinking skills among technical students.Social and Behavioral Sciences, 204, 143-152. 